\title{
Confirmation of the experimentally measured cooling time of Polyethylene Terephthalate (PET) melt by ANSYS and FORTRAN
}

\author{
Bilal DEMIREL ${ }^{1, *}$, Mustafa DANACI ${ }^{2}$, Fatih AKKURT ${ }^{3}$, Ali YARAŞ ${ }^{4}$ \\ ${ }^{1}$ Erciyes University, Department of Material Science and Engineering, Kayseri, Turkey \\ ${ }^{2}$ Erciyes University, Department of Computer Engineering, Kayseri, Turkey. \\ ${ }^{3}$ Gazi University, Department of Chemical Engineering, Ankara, Turkey. \\ ${ }^{4}$ Bartın University, Department of Metallurgy and Material Engineering, Bartın, Turkey. \\ Geliş Tarihi (Received Date): 25.01.2021 \\ Kabul Tarihi (Accepted Date): 23.05.2021
}

\begin{abstract}
This study deals with confirmation of the experimentally measured cooling/solidification time of the Polyethylene Terephthalate (PET) melt by ANSYS and FORTRAN analysis programs. Therefore, a new code was written and run by using FORTRAN programming. With the ANSYS Thermal Transient module, cooling time and the injection conditions of PET into a cylindrical mold were simulated. Then, the experimental results and the analysis data were compared. It was determined that the results are in good agreement $(100 \%)$ in case of heat capacity $\left(C_{p}\right)$ value is chosen depending on the temperature. The results show that the proposed new codes will contribute to the optimization of cooling/solidification time for industrial scale PET production.
\end{abstract}

Keywords: Polyethylene Terephthalate (PET), solidification time, cooling time, FORTRAN, ANSYS.

\footnotetext{
*Bilal DEMIREL, bilaldemirel@erciyes.edu.tr, https://orcid.org/0000-0002-5390-0630

Mustafa DANACI, danaci@erciyes.edu.tr, https://orcid.org/0000-0002-2430-6106

Fatih AKKURT, fatihakkurt@gazi.edu.tr, https://orcid.org/0000-0002-3509-2246

Ali YARAŞ, aliyaras@bartin.edu.tr, https://orcid.org/0000-0003-1725-7788
} 


\section{Polietilen Teraftalat (PET) eriyiğinin deneysel olarak ölçülen soğutma süresinin ANSYS ve FORTRAN tarafindan doğrulanmas1}

\section{$\ddot{\mathbf{O} z}$}

Bu çalışma, Polietilen Tereftalat (PET) eriyiğinin deneysel olarak ölçülen soğutma süresinin soğutma/katılaşma süresinin ANSYS ve FORTRAN analiz programları tarafından doğrulanması ile ilgilidir. Bunun için, FORTRAN programı kullanılarak, yeni bir kod yazıldı ve çalıştırıldı. ANSYS Thermal Transient modülü ile soğutma süresi ve PET'in silindirik kalıba enjeksiyon koşulları simüle edildi. Sonrasında, deneysel sonuçlar ve analiz verileri karşılaştırıldı. Isı kapasite $\left(C_{p}\right)$ de ğerinin sıcaklı̆̆a bă̆ll olarak seçilmesi durumunda sonuçların uyum içinde olduğu (\%100) tespit edildi. Sonuçlar, önerilen yeni kodların endüstriyel ölçekte PET üretimi için soğutma/katılaşma süresinin optimizasyonuna katkıda bulunacağını göstermektedir.

Anahtar kelimeler: Polietilen Teraftalat (PET), katılaşma süresi, soğutma zamanı, FORTRAN, ANSYS.

\section{Introduction}

The use of polymers such as PP, PET, PC, PMMA, PE, ABS, which are one of the most consumed materials in our daily life, is increasing day by day. The following four methods are generally preferred for processing polymers; injection, extrusion, blow moulding and rotational moulding. In the mentioned methods, the polymer is heated to its melting temperature to take the shape of the mould. The outer surface of the mould is cooled with cooling water under the glass transition temperature $\left(\mathrm{T}_{\mathrm{g}}\right)$ and the polymeric material is removed from the mould. The process parameters play a critical role on the physical and chemical properties of the produced polymeric material. One of these parameters is the residence time in the mould. If the product keeping time in the mould is too short, the product may be deformed while ejecting out of the mould. However, if the residence time is too long, both the production speed decreases and the energy cost increases. For optimum temperature for demoulding, the product surface temperature should be below Tg. The knowing the solidification temperature allows the on/off settings of the mould cooling water channels. The errors in the opening timing of the cooling channels cause the molten polymer to block the injection path and cause defective product to be produced because of insufficient cooling. Besides, material cooling time is a critical parameter to be known in machine efficiency calculations in injection moulding process. Although there are numerous experimental studies on the solidification/cooling time of polymers in injection moulding, differences between formulas used in calculations are remarkable. Stelson [1] calculated the cooling time according to the midplane and average temperature using the previous equations in literature. It was reported that most cooling time formulas for injection moulding contain errors, deviations occur for thin and thick materials. In recent years, a number of computer-based numerical models were improved for injection moulding process. However, due to simplicity and convenience, the closed form analytical expressions are still the preferred methods for calculating the cooling times in the initial process design and cost estimation [1]. Yu and Sunderland [2] and Liang and Ness [3] stated that several equations were used in the cooling time calculation 
and this caused uncertainty. The cooling formulas of simple shapes such as spheres and cylinders are listed by Dietzel et al. [4] and Menges et al. [5]. They noted that the most commonly used formulas are for those with infinite width and finite thickness. The cooling time formulas for plates are generally as follows:

$$
t_{c}=\frac{c_{0} a^{2}}{\alpha} \ln \left[c_{1}\left(\frac{T_{i}-T_{f}}{T_{e-} T_{f}}\right)\right]
$$

where $t_{c}$ is the cooling time, $a$ is the thickness, $\alpha$ is the thermal diffusivity of the polymer, $T_{i}$ is the initial temperature of the polymer melt, $T_{f}$ is the mould temperature and $T_{e}$ is the ejection temperature of the part. The heat detection temperature of the material is often taken as an acceptable value for $T_{e}$ [1]. Equation (1) may be written in dimensionless form as follows:

$$
F=c_{0} \ln \left(\frac{c_{1}}{Y}\right)
$$

where $F=\left(\frac{t_{c} \alpha}{a^{2}}\right)$ is the dimensionless cooling time or Fourier number, and $Y=\frac{T_{e-} T_{f}}{T_{i}-T_{f}}$ is the dimensionless ejection temperature [1]. The equation number 3 is a general and comprehensive one and was used as the basis for calculations in the present study. In this equation, the mould $\left(\mathrm{T}_{\mathrm{f}}\right)$ and polymer initial $\left(\mathrm{T}_{\mathrm{i}}\right)$ temperature are constant. It may be also assumed that thermal contact between the polymer and mould is perfect and thermal diffusivity of the cooling polymer is constant $[6,7]$ :

$$
\frac{T(y, t)-T_{f}}{T_{i}-T_{f}}=2 \sum_{n=0}^{\infty} \frac{\left(1^{n}\right)}{(n+1 / 2) \pi} e^{(n+1 / 2)^{2} \pi^{2} \alpha t / b^{2} \cos \left(n+\frac{1}{2}\right) \frac{\pi y}{b}}
$$

where $\mathrm{T}_{(\mathrm{y}, \mathrm{t})}$ is the temperature distribution within the polymer as a function of time, $\mathrm{t}$, and position, $y$. The $y$ axis has its origin at the mid-plane of the part, and $b=a / 2$ is the part half-thickness. In equation-3, the mold temperature $\left(\mathrm{T}_{\mathrm{f}}\right)$, PET temperature $\left(\mathrm{T}_{\mathrm{i}}\right)$ and $\pi$ values were taken as $20^{\circ} \mathrm{C}, 260^{\circ} \mathrm{C}$ and 3.14 , respectively. Thermal diffusivity $(\alpha)$ was calculated according to $\alpha=\frac{\text { Thermal conductivity }}{\text { Density. } C_{p}}$ equation. Thermal conductivity, density and $C_{p}$ values for $\alpha$ calculations were received as $0.225 \mathrm{~W} / \mathrm{m} . \mathrm{K}, 1376 \mathrm{~kg} / \mathrm{m}^{3}$ and 816 $\mathrm{J} / \mathrm{kg} . \mathrm{K}$, respectively.

$$
\begin{aligned}
& T(y, t)=2 \sum_{n=0}^{\infty} \frac{\left.4\left(T_{i}-T_{f}\right)\right)}{\pi} e^{\pi^{2} \alpha t / a^{2}} \cos \frac{\pi y}{a}+T_{f} \\
& t_{c}=\frac{a^{2}}{\pi^{2} \alpha} \ln \left[\frac{4}{\pi}\left(\frac{T_{i}-T_{f}}{T_{e}-T_{f}}\right)\right] \\
& t_{c}=\frac{a^{2}}{\pi^{2} \alpha} \ln \left[\frac{8}{\pi^{2}}\left(\frac{T_{i}-T_{f}}{T_{e}-T_{f}}\right)\right]
\end{aligned}
$$

Ballman and Shusman [8] state the cooling time equation as;

$t_{c}=\frac{a^{2}}{2 \pi \alpha} \ln \left[\frac{\pi}{4}\left(\frac{T_{e-T_{f}}}{T_{i}-T_{f}}\right)\right]$

It is essential to be known the cooling time for the effective cost analysis of the materials to be injection moulded. For this purpose, formulation that is basic but gives accurate result is required. The formulae derived so far contain some errors a certain extent. 
Stelson has concluded that if the ejection criterion was based on mid-plane temperature, equation-5 was correct, but if the ejection criterion was based on average temperature, equation-6 was correct.

All other equations given in literature were investigated in reference [1] in detail. In each of them, thermal diffusivity was taken constant. However, this parameter depends on thermal heat capacity $\left(C_{p}\right) . C_{p}$ value changes with the change of temperature. Therefore, the results for the above equations contain minor errors. That is why, to achieve more correct results, $C_{p}$ value should be calculated for each temperature. To this end, in our calculations, $C_{p}$ value was calculated for each temperature using FORTRAN programming.

Simulation and calculation methods were developed as a result of the theoretical and experimental studies carried out to determine the injection time. Some of the programs with commercial versions are; ANSYS, Moldflow, BlowView, BlowSim. However, it is not known exactly how well these programs are compatible with experimental data. In this study, it was aimed to write a code to obtain data on the cooling curve of PET. The obtained cooling curve data were compared with ANSYS results and experimental data. The number of studies on simulation of heating and cooling processes of injection moulded plastic materials is limited in literature. An automotive interior material's heating and cooling channels design and its evaluation in rapid heat cycle moulding were studied by Wang et al.[9]. Hassan et al. [10]reported that the design of the cooling system was not suitable for the minimum cooling time and caused non-uniform cooling throughout the mould. As for Li et al. [11], they have worked out about automatic layout design of cooling design of plastic parts to be injection moulded. Besides, the effect of the cooling system on the shrinkage and temperature of the moulded polymer injected into the cooling system was simulated by Li [12]. It was stated that the location of the cooling channels is important for the production of quality products and this greatly affects the final product temperature and shrinkage rate [12]. In another study, a simplified heat transfer model and equation for the calculation of cooling time in injection moulding is presented by Liang and Ness [3]. Bendada et al. [13] revealed that the thermal contact resistance between the mould and the polymer in injection moulding is not negligible, is related to processing conditions, and is not stable over time. $\mathrm{Li}$ and $\mathrm{Li}$ [14] analysed a plastic injection mould cooling system using the configuration space method. The accuracy of the formulas used in studies on the cooling time of polymers in injection moulding is a debatable issue. In addition, the number of studies on cooling time and solidification is also limited. In the present paper, equation number-3 was taken into consideration and the code written by FORTRAN programming was run. The injection of PET into a cylindrical mould and the cooling time were simulated using the ANSYS Thermal Transient module. Following that, the analysis results were compared with experimental data. 


\section{Experimental studies}

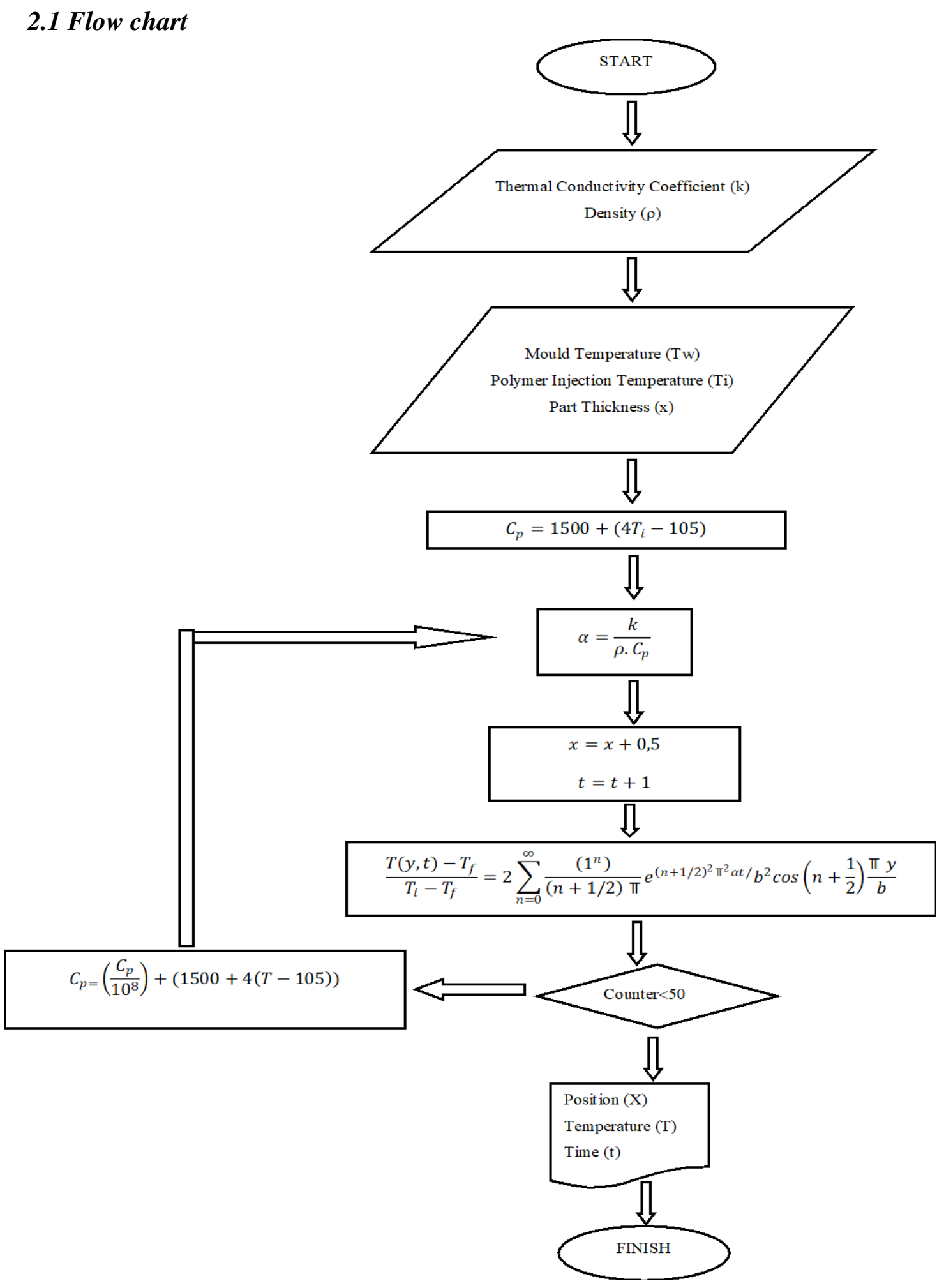

Figure 1. Algorithm used in writing code with FORTRAN.

The flow chart formed for the problem to be solved by a computer programming is given in Figure 1. As the $C_{p}$ value of materials is dependent on temperature, $C_{p}$ value of PET 
was re-calculated in every cycle for changing temperature in this study. In every new calculation, a new value of the $\mathrm{C}_{\mathrm{p}}$ was used corresponding to the related temperature.

\subsection{Fortran code writing}

FORTRAN computer programming was used in the solution of the problem whose flow chart is given above. A small part of the written program is given below (pseudo code).

DO $40 \times 1=0,(X / 2+0.01), 0.4$

$\mathrm{L}=\mathrm{L}+1$

FTOTAL=0

DIFF=TCOND/(DENSITY*CP)

DO $10 \mathrm{~N}=0,600$

$\mathrm{X} 2=(\mathrm{X} * 1 \mathrm{E}-3) / 2$

$\mathrm{F} 1=((-1) * * \mathrm{~N}) /((\mathrm{N}+(0.5)) * \mathrm{PI})$

$\mathrm{F} 2=\operatorname{EXP}(-1 *(((\mathrm{~N}+(0.5)) * * 2) *(\mathrm{PI} * * 2) * \mathrm{DIFF} * \mathrm{TIME}) /(\mathrm{X} 2 * * 2))$

$\mathrm{F} 3=(\mathrm{N}+(0.5)) * \mathrm{PI} *((\mathrm{X} 1 * 1 \mathrm{E}-3) / \mathrm{X} 2)$

$\mathrm{F} 4=\mathrm{COS}(\mathrm{F} 3)$

FTOTAL1=F1*F2*F4

FTOTAL=FTOTAL+FTOTAL1

10 CONTINUE

IF (TIME.EQ.0)THEN

TEMP=TI

GOTO 90

Figure 2. Code written with FORTRAN for calculation of cooling time.

\subsection{ANSYS analysis}

Verification the results after processing the FORTRAN code given above was tested with the commercial version of the ANSYS Workbench program steady-state thermal module. Cylindrical mould design used in the experimental section of the study was drawn using Space-Claim Design Modeler and the analysis were carried out by the aforementioned program. 


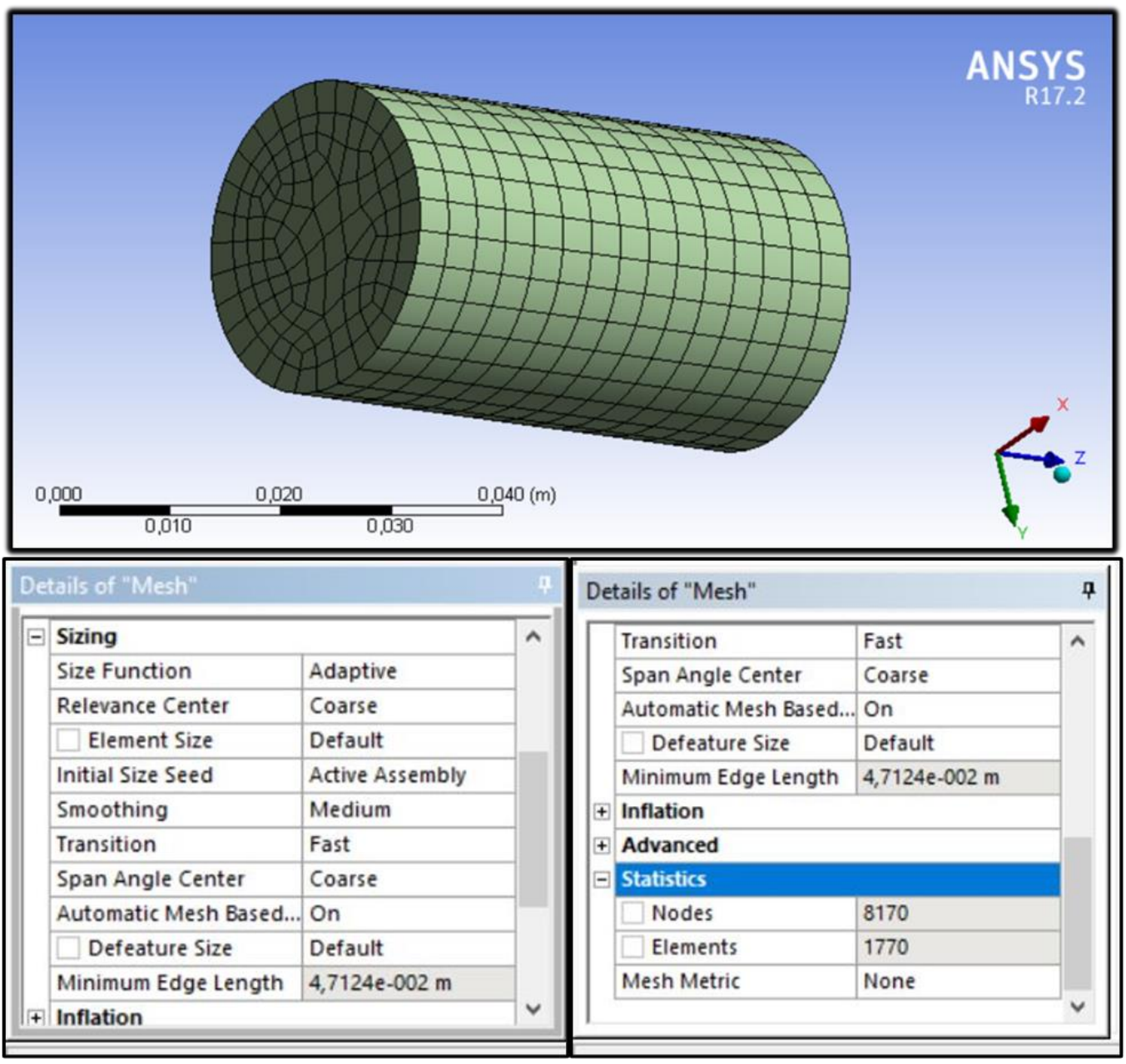

Figure 3. Mesh formed on the design with ANSYS Thermal Transient analysis.

In thermal analyses, injection temperature of the product inside the mould and the environment temperature were taken to be $260^{\circ} \mathrm{C}$ and $20^{\circ} \mathrm{C}$, respectively. Due to the simplicity of the mould used in the study, coarse mesh type was selected. The mould and analysis application are shown in Figure 3.

\subsection{Practical application}

In this study, a simple cylindrical tin mould with diameter of $30 \mathrm{~mm}$ and length of 100 $\mathrm{mm}$ was used. After filling the PET granules into the mould, the mould was placed in an oven to provide PET melt heating up to $260^{\circ} \mathrm{C}$. To allow uniform temperature distribution in the mould, the PET melt was continuously stirred for a period of time. After obtaining a uniform temperature distribution, the mould was placed in a water bath with a constant temperature of $20^{\circ} \mathrm{C}$ to cool the PET melt and the temperature measurement was then performed with a wire thermometer from the centre of the mould depending on time. On the other hand, a second temperature control was provided by a thermal camera branded FLIR Thermal Camera. 


\section{Results and discussion}

\subsection{FORTRAN programming results}

Time-dependent temperature values taken from the centre of the cylindrical mould for PET sample are given in Table 1. Depending on the time, the temperature values of the points at a certain distance from the centre of the cylindrical part are given in Figure 4.

Table 1. Time-dependent temperature values taken from the centre of the mold.

\begin{tabular}{|c|c|c|c|c|c|}
\hline No & $\begin{array}{c}\text { Time } \\
(\mathbf{s e c})\end{array}$ & $\begin{array}{c}\text { Temperature } \\
\left({ }^{\circ} \mathbf{C}\right)\end{array}$ & No & $\begin{array}{c}\text { Time } \\
(\mathbf{s e c})\end{array}$ & $\begin{array}{c}\text { Temperature } \\
\left({ }^{\circ} \mathbf{C}\right)\end{array}$ \\
\hline 1 & 0 & 260 & 11 & 300 & 210 \\
\hline 2 & 30 & 258 & 12 & 330 & 202 \\
\hline 3 & 60 & 258 & 13 & 360 & 194 \\
\hline 4 & 90 & 257 & 14 & 390 & 187 \\
\hline 5 & 120 & 255 & 15 & 420 & 180 \\
\hline 6 & 150 & 248 & 16 & 450 & 173 \\
\hline 7 & 180 & 242 & 17 & 480 & 165 \\
\hline 8 & 210 & 235 & 18 & 510 & 158 \\
\hline 9 & 240 & 227 & 19 & 540 & 150 \\
\hline 10 & 270 & 219 & 20 & 570 & 145 \\
\hline & & & 21 & 600 & 140 \\
\hline
\end{tabular}

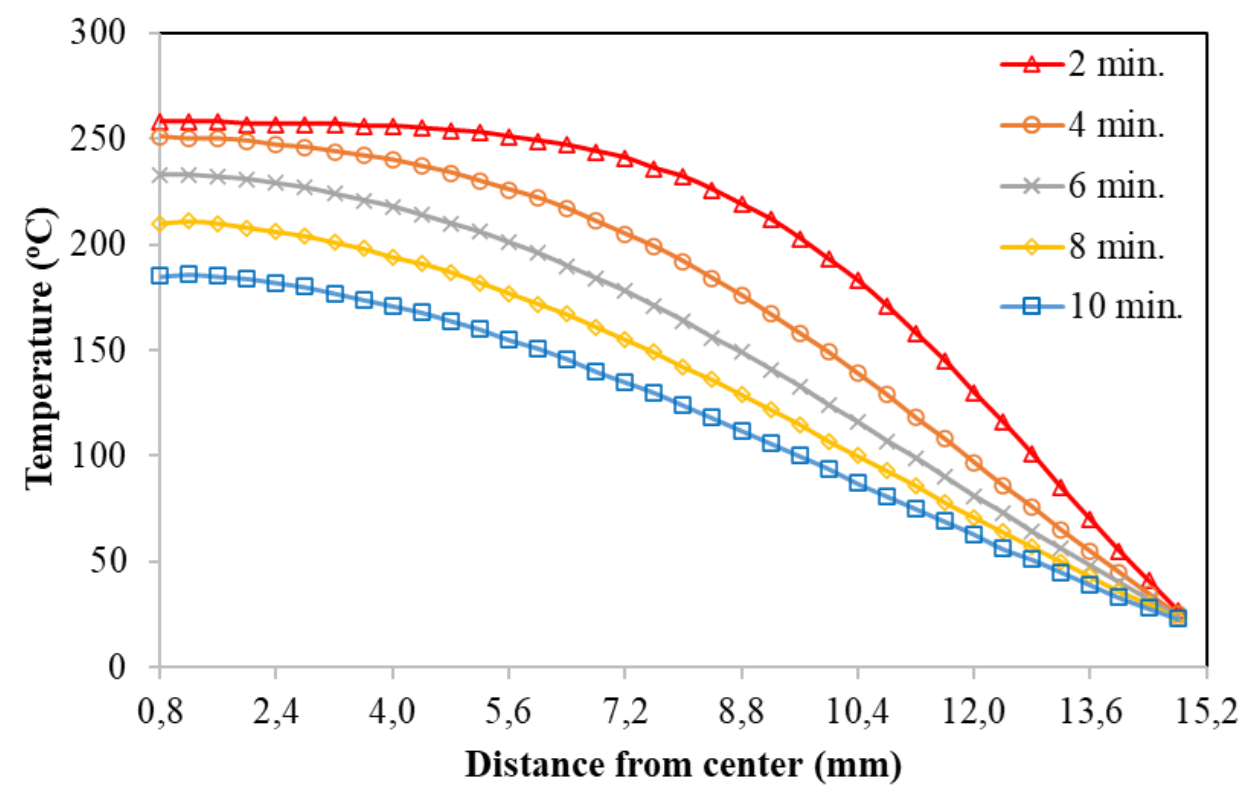

Figure 4. Temperature values at the certain distances from the centre of the part depending on time.

As seen from Figure 4, the temperature decreases as moving away from the centre of the part injected into mould, and at last reaches at mould surface temperature. On the other hand, the temperatures at the other points outside the centre of the part also decrease over time. According to the results, it is very difficult to produce a completely transparent material using PET. The parts contacting the surface of the mould will be transparent, but the centre of the part will turn into a crystalline structure due to the slow cooling. 


\subsection{ANSYS analysis results}

Time-dependent temperature values taken from the centre of the cylindrical mold for PET sample are given in Table 2.

Table 2. Time-dependent temperature values taken from the centre of the mold.

\begin{tabular}{|c|c|c|c|c|c|}
\hline No & $\begin{array}{c}\text { Time } \\
(\mathbf{s e c})\end{array}$ & $\begin{array}{c}\text { Temperature } \\
\left({ }^{\circ} \mathbf{C}\right)\end{array}$ & No & $\begin{array}{c}\text { Time } \\
(\mathbf{s e c})\end{array}$ & $\begin{array}{c}\text { Temperature } \\
\left({ }^{\circ} \mathbf{C}\right)\end{array}$ \\
\hline 1 & 0 & 260 & 11 & 300 & 220 \\
\hline 2 & 30 & 258 & 12 & 330 & 212 \\
\hline 3 & 60 & 258 & 13 & 360 & 220 \\
\hline 4 & 90 & 257 & 14 & 390 & 196 \\
\hline 5 & 120 & 257 & 15 & 420 & 188 \\
\hline 6 & 150 & 251 & 16 & 450 & 181 \\
\hline 7 & 180 & 247 & 17 & 480 & 173 \\
\hline 8 & 210 & 241 & 18 & 510 & 166 \\
\hline 9 & 240 & 234 & 19 & 540 & 157 \\
\hline 10 & 270 & 227 & 20 & 570 & 152 \\
\hline & & & 21 & 600 & 145 \\
\hline
\end{tabular}

The results obtained by ANSYS Thermal Transient analysis method are given in Figure 5. As can be seen form Figure 5, while the regions near the centre of the part slowly cool down, the regions where the temperature is much lower will cool more rapidly, due to the equation-3 having an exponential factor.

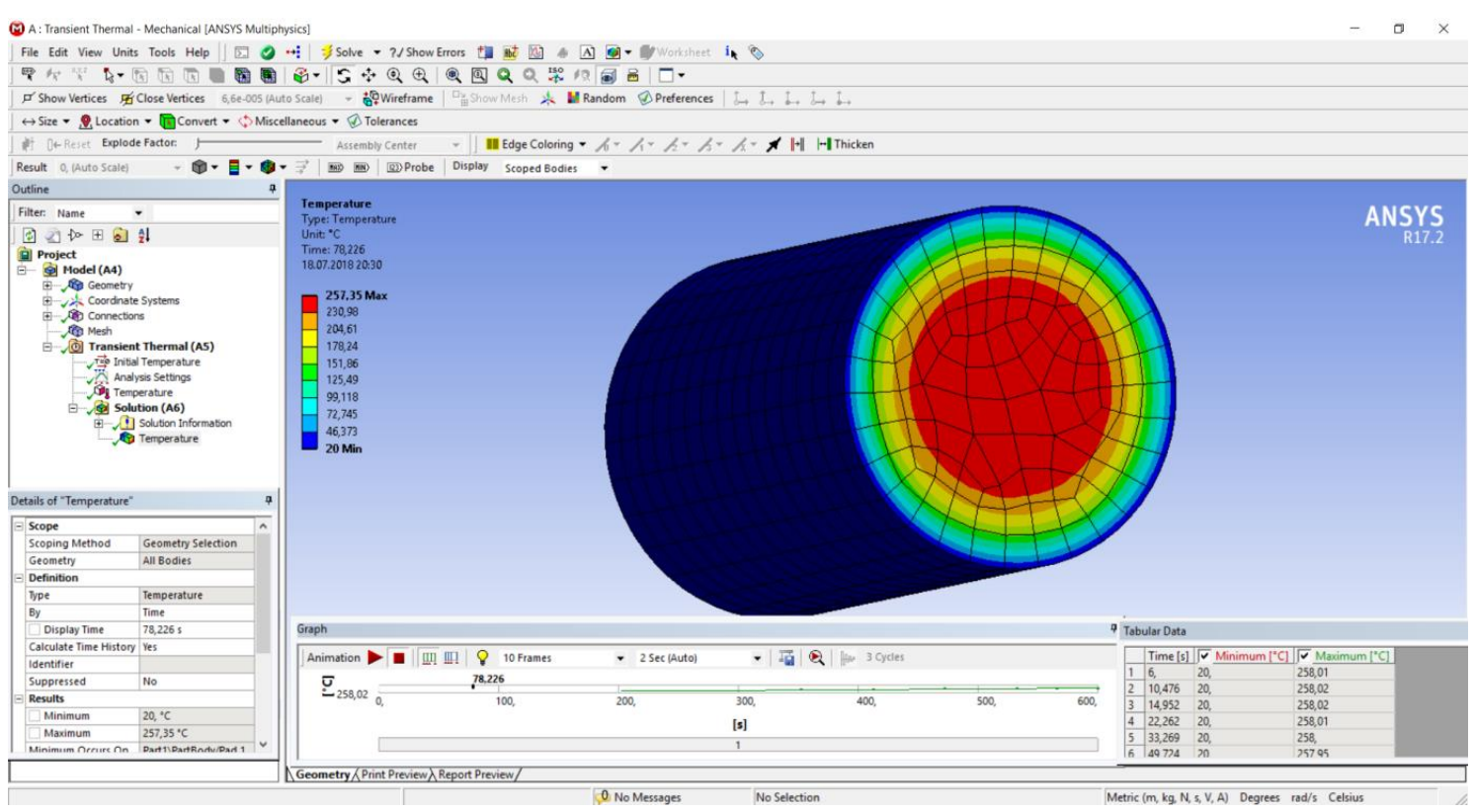

Figure 5. Screenshot for ANSYS thermal analysis.

\subsection{Experimental test results}

Time-dependent temperature values taken from the centre of the cylindrical mould for PET sample are given in Table 3. Temperature measurements have been carried out using thermal camera and wire thermometer. Measurements taken from different points by 
thermal camera have been given in Figure 6. It is very important to adjust the thermal emission constant of the used thermal camera according to the material used to obtain the correct result.

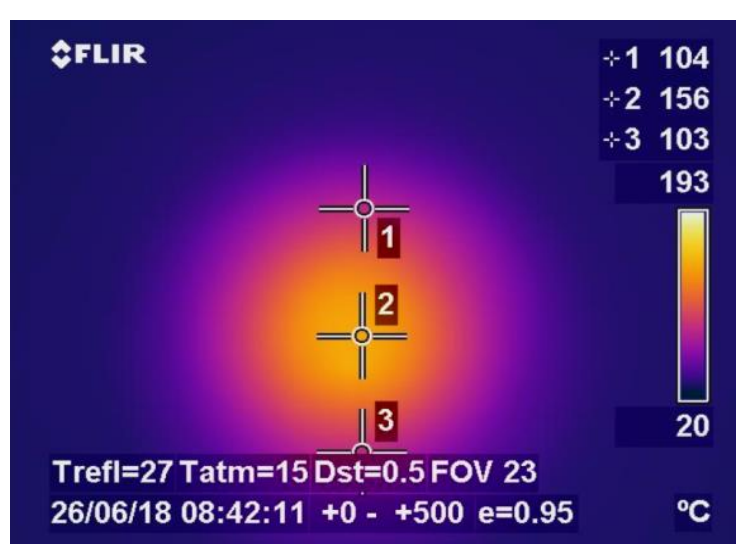

Figure 6. Measurement with the thermal camera used in the experiments.

Table 3. Time-dependent temperature values taken from the centre of the mold.

\begin{tabular}{|c|c|c|c|c|c|}
\hline No & $\begin{array}{c}\text { Time } \\
(\mathbf{s e c})\end{array}$ & $\begin{array}{c}\text { Temperature } \\
\left({ }^{\circ} \mathbf{C}\right)\end{array}$ & No & $\begin{array}{c}\text { Time } \\
(\mathbf{s e c})\end{array}$ & $\begin{array}{c}\text { Temperature } \\
\left({ }^{\circ} \mathbf{C}\right)\end{array}$ \\
\hline 1 & 0 & 260 & 11 & 300 & 218 \\
\hline 2 & 30 & 257 & 12 & 330 & 214 \\
\hline 3 & 60 & 255 & 13 & 360 & 205 \\
\hline 4 & 90 & 255 & 14 & 390 & 196 \\
\hline 5 & 120 & 253 & 15 & 420 & 190 \\
\hline 6 & 150 & 241 & 16 & 450 & 176 \\
\hline 7 & 180 & 240 & 17 & 480 & 172 \\
\hline 8 & 210 & 238 & 18 & 510 & 156 \\
\hline 9 & 240 & 230 & 19 & 540 & 154 \\
\hline 10 & 270 & 224 & 20 & 570 & 146 \\
\hline & & & 21 & 600 & 144 \\
\hline
\end{tabular}

\subsection{Comparison of the studied three methods}

The concentration point of the study carried out is the experimentally testing of the accuracy of both the commercially used ANSYS Transient Thermal analysis module and the theoretically derived equation. As seen in Figure 7, the values obtained by all three methods are in great agreement. However, it is seen that ANSYS values are slightly high, but this is too small. 


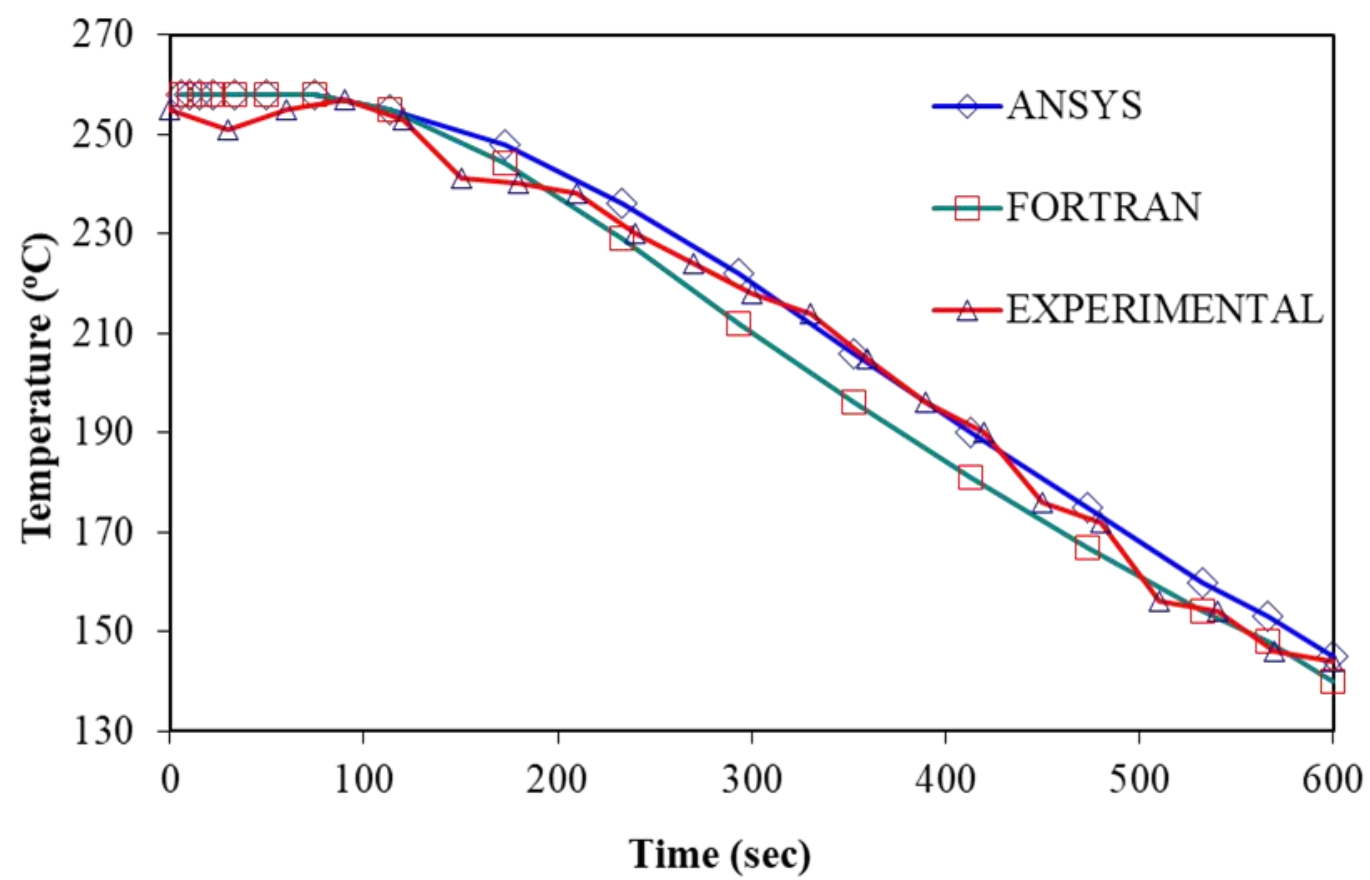

Figure 7. Comparison of experimental data with FORTRAN and ANSYS analysis results.

\section{Conclusion}

In the present study, the accuracy of the data obtained with ANSYS Thermal Transient Module were compared and tested by the data obtained with both experimental study and FORTRAN programming written by using the equation, which has been derived for cooling time of the cylindrical parts in literature. FORTRAN code writing is based on the above-mentioned equation-3, which is the equation that gives the best relationship between position, time and temperature. In general, the $C_{p}$ value has been taken to be constant in the calculations so far, but this has caused some degree of errors. In the present study, it was observed that the data obtained with ANSYS transient thermal were consistent with the experimental data and approach $100 \%$ in case $C_{p}$ value in the equation number-3 was selected to be dependent on temperature. In this study, both the written code, ANSYS Transient module and equation-3 were found to be compatible with each other.

\section{Acknowledgement}

This paper is granted to Assist Dr. Mustafa DANACI who recently passed away and whom we respected and will always miss.

\section{References}

[1] Stelson, K.A. Calculating cooling times for polymer injection moulding, Proceedings of the Institution of Mechanical Engineers, Part B: Journal of Engineering Manufacture, 217, 5, 709-713, (2003)

[2] Yu, C.J. and Sunderland, J.E. Determination of ejection temperature and cooling time in injection molding, Polymer Engineering \& Science, 32, 3, 191-197, (1992) 
[3] Liang, J.Z. and Ness, J.N. The calculation of cooling time in injection moulding, Journal of Materials Processing Technology, 57, 62-64, (1996)

[4] Dietzel, H. Schumann, J. Müller, K. Kühl-und Siegelzeit analytisch berechnen, Kunststoffe, 81, 1138-1140, (1991)

[5] Menges, G. Michaeli, W. Mohren, P. How to make injection molds, Carl Hanser Verlag GmbH Co KG, 271-283, (2013)

[6] Bird, R.B. Stewart,W.E. Lightfoot, E.N. Transport Phenomena, John Wiley \& Sons, New York, 413, 354-357, (1960)

[7] Jaeger, J.C. and Carslaw, H.S. Conduction of heat in solids, Clarendon Press, Oxford, 100, (1959)

[8] Ballman, R.L. and Shusman, T. Easy way to calculate injection molding set-up time, Modern Plastics, 194, 130-131, (1959)

[9] Wang, G. Zhao, G. Wang, X. Heating/cooling channels design for an automotive interior part and its evaluation in rapid heat cycle molding, Materials \& Design, 59, 310-322, (2014)

[10] Hassan, H. Regnier, N. Lebot, C. Pujos, C. Defaye, G. Effect of cooling system on the polymer temperature and solidification during injection molding, Applied Thermal Engineering, 29, 1786-1791, (2009)

[11] Li, C.L. Li, C.G. Mok, A.C.K. Automatic layout design of plastic injection mould cooling system, Computer-Aided Design, 37, 645-662, (2005)

[12] Li, C.L. A feature-based approach to injection mould cooling system design, Computer-Aided Design, 33, 1073-1090, (2001)

[13] Bendada, A. Derdouri, A. Lamontagne, M. Simard, Y. Analysis of thermal contact resistance between polymer and mold in injection molding, Applied Thermal Engineering, 24, 2029-2040, (2004)

[14] Li, C.G. and Li, C.L. Plastic injection mould cooling system design by the configuration space method, Computer-Aided Design, 40, 334-349, (2008) 